PEOPLE: International Journal of Social Sciences

ISSN 2454-5899

Houston et al.

Special Issue Volume 2 Issue 1, pp. 685-705

Date of Publication: 15 th December, 2016

DOI-https://dx.doi.org/10.20319/pijss.2016.s21.685705

\title{
COOPERATION IN WORK-ORIENTED LEARNING IN HIGHER EDUCATION
}

\author{
Muir Houston \\ College of Social Sciences, School of Education, Social Justice Place Lifelong Ed, University \\ of Glasgow, R223 Level 2, St Andrews Building, United Kingdom \\ Muir.Houston@glasgow.ac.uk \\ Karsten Krüger \\ Fundación Conocimiento y Desarrollo, Pl. Francesc Macià, 4, 08021 Barcelona, Spain. \\ Karsten.Krueger@fundacioncyd.org
} 43006-Tarragona, Spain

Alba.Molas@urv.cat

Mike Osborne

College of Social Sciences, School of Education, Social Justice Place Lifelong Ed, University of Glasgow, R223 Level 2, St Andrews Building, United Kingdom

Michael.Osborne@glasgow.ac.uk

Laureano Jiménez

Departament d'Enginyeria Química, Universitat Rovira i Virgili, Av. Països Catalans, 26, 43006-Tarragona, Spain

Laureano.Jimenez@urv.cat

\begin{abstract}
The paper reports on preliminary findings from an EU funded project on collaboration and partnership between external stakeholders and universities to deliver work-related learning to adults with existing labour market experience in order to increase skills and competences for the knowledge economy as envisaged in Agenda 2020. The paper engages with debates on the professionalization of vocational education and consequently the vocationalisation of
\end{abstract}


university education. It reports relevant data for the six partner countries of the LETAE project and EU averages to provide some context to debates about relative levels of attainment and labour market position. It briefly introduces some data drawn from cases studies of work-related learning in higher education delivered in partnership or collaboration with external stakeholders including local authorities, trade unions, and individual enterprises. Finally, it compares in detail the cases from the UK and Spain as illustrative of specific national responses to work-related learning initiatives.

\section{Keywords}

Work-related learning; higher education, VET; permeability; external stakeholders; EU; attainment; labour markets; partnership.

\section{Work oriented learning in higher education}

Higher education (HE) has in the last few decades experienced a considerable transformation, which can be identified by two trends:

a) Academic drift in the sense of traditional vocational education at secondary and postsecondary level becoming 'professional' at tertiary 'academic' education level (Kyvik, 2004; Harwood, 2010).

b) Vocational drift whereby VET principles are integrated into higher education in the form of new teaching and learning methods, internships and different types of dual studies and sandwich programmes (Kyvik, 2008; Hippach-Schneider, 2014).

Both trends can be subsumed under the term of the vocationalisation of higher education. Alongside other drivers such as technological developments and structural changes in the economy that influenced the labour market; the main driving force of change in HE was the increasing massification of higher education accompanied by the universalisation of the higher education offer (Trow, 1974). The objective of the new EU strategy is to achieve a goal of $40 \%$ of 25-35 year olds in higher education consolidating the trend towards universalisation.

One significant effect of the increasing proportion of the population accessing and participating in higher education is that of 'crowding out'. Simply put, changes in the supply of graduates have not been matched by changes in demand in the labour market; thus it is 
suggested that those graduates, who are unable to find employment in the traditional areas requiring academic qualifications, enter into the 'non-academic' labour market. This trend is said to have contributed to a re-definition of occupational profiles including a stronger academic orientation and in consequence, an increase in the demand for academic qualifications in occupations previously intended for those with primarily vocational qualifications. Smeby (2015) analysed this process for teaching, nursery and social work, where the process of upgrading from vocational programmes to higher education has been taking place for the last 40 years. Elsewhere in the labour market this has led to changes in the demand for skills as a result of changes to the manufacturing and service processes though technological change and innovation. It is suggested that this has increased demand for more generic analytical skills and reduced demand for narrowly defined job-specific skills (Mayer \& Solga, 2008: 1-4; Solga, 2009; Streeck, 2011). Moreover, the rise in the level of average skill requirements in the service economy and knowledge society (e.g., Kuhn et al., 2009; Buhr et al., 2008, Jung 2015) brings into question the traditional divide between VET and HE, producing a vocationalisation of HE. At the same time, as Skorstad and Ramsdal (2009) explain, the removal of traditional job demarcations inherent to job specific skills has had the effect of introducing functional flexibility which allows for the employment of semiskilled or unskilled labour. Those with academic qualifications, particularly young workers desperate for employment, fall into this category of under-employment (Bell \& Blanchflower, 2013; Allen, 2015). At the same time, the EU goal of $40 \%$ entering HE, taken up enthusiastically by governments across the EU, together with the continuing aftermath of the 2008 Great Financial Crisis, has resulted in employers having a much bigger pool of labour from which to choose (Standing, 2011) so the call for greater permeability between the fields of VET and HE has become more strident.

One major expression of the structural changes is the curricular reforms to implement the three-cycle structure promoted by the Bologna Process. It stated that Bachelor degrees should have a strong orientation to the labour market i.e. to employability, and concomitant a stronger vocational orientation.

A second factor is the existence of additional certificates below the Bachelor degree with a stronger vocational orientation (for instance the French Brevet de Technician Supérieur (BTS) or the Foundation Degree in England, Wales and Northern Ireland). 
A third factor is the introduction of specialist degrees (generally at Bachelor level) with long periods of workplace learning, such as Dual Studies (e.g., Germany and Austria), Alternance Programs (France) and Sandwich Programmes (UK). In some countries, there is a trend to distinguish between professional and academic masters (CEDEFOP, 2011).

A fourth factor is innovations in teaching and learning; mainly concerned with introducing workplace learning into the curriculum, or to simulate real work situations through strategies such as Cooperative Learning, Problem Based Learning, Project Oriented Learning and, most recently, Service Learning and Research Based Learning (Yorke and Knight, 2006; Kitching, 2015). Specifically in relation to employability increasing number of degree programmes are offering some form of internship or placement to students during their undergraduate study. However, these changes are not only designed to respond to vocationalisation, but also to policy initiatives, designed to ensure closer cooperation and greater engagement between employers and enterprises and universities in order to respond more effectively to the challenges of the knowledge economy; and changes in research procedures, which are increasingly focused on public-private cooperation and interdisciplinary work.

A fifth factor is the degree of permeability between VET and HE expressed through the Recognition of Prior Learning (RPL) and the Accreditation of Prior Leaning (APL). R/APL is a priority for educational policies Europe-wide and on the agenda of many European countries; and, while in theory it is available in some member states, as suggested in the European Credit Transfer System (EC, 2015), its acceptance and the level and amount of credit awarded varies both within and across member states (Lafont and Pariat, 2012). The introduction of R/APL is a way to establish new and more flexible education trajectories allowing the transition between VET and HE; and, again, moves in this direction have been made at both the EU level with the introduction of the EQF (European Qualification Framework) and similar moves in member states in the development of NQFs (National Qualifications Frameworks). However, as with the ECTS, progress is varied (CEDEFOP, 2102).

Last but not least, the vocationalisation of HE introduced closer university-business cooperation in the field of education. It is seen as crucial to the employability agenda for greater integration of internships and placements into the formal university curriculum. This 
cooperation in the field of education is accepted Europe-wide as of major importance, but effective cooperation differs from country to country. For instance, a number of EU documents have argued for a deeper engagement with stakeholders (EUNEC, 2011; EC, 2012), especially from business in the definition and in some cases co-construction of the higher education curriculum.

It is recognised that curriculum development is often slow to respond to changes in the labour market and work requirements (Krüger and Jiménez, 2008). But Teichler drew attention to the opinion of stakeholders on developments in the labour market often being mistaken as objective information. The debate on the involvement of stakeholders in curriculum design is linked to the type of knowledge, skills and competence higher education is expected to deliver. Higher education knowledge, skills and competence differ substantially from those associated with other levels of education and training institutions.

Higher education systems need to increase lifelong learning opportunities, widen access to higher education, booster employability and upgrade the skills of the population. This include the broader integration of non-traditional learners in the programmes of the Bologna scheme, but also the offer of specific programme for adult learners, which will have a primarily labour market orientation. In the strategy paper Supporting growth and jobs - an agenda for the modernisation of Europe's higher education systems (EC, 2011) one of the key policy issues is to encourage a greater variety of study modes (e.g., part-time, distance and modular learning, continuing education) for adult returners and others already in the labour market).

\section{The Projects}

In the following section, we present some preliminary results from the study on university-enterprise cooperation in the field of tertiary lifelong learning (TLL) and university adult education; or, what under the Liberal Arts Education tradition in the UK would be seen as Continuing Education.

The Labour Efficiency of Tertiary Adult Education (LETAE) project (funded by the EU under its Lifelong Learning Programme) was concerned to identify good practice in partnerships and collaborations between enterprises, work organisations and employer groups and higher education institutions. In LETAE we explored work-based/-related elements of such programmes with a focus on partnerships and collaborations with external stakeholders. 
The project aimed to identify areas of good practice in the development of programmes in collaboration with industry, employers, sectoral organisations, trade unions and professional or regulatory bodies. We were also concerned with what the drivers of such programmes are in terms of internal or external factors; and, how and in what ways national policy contexts, regulatory frameworks and labour market structures may influence this process. The project contribute providing answers to the following research questions:

- To what extent are universities cooperating with enterprises and external stakeholders in the field of university adult education?

- Will this cooperation lead to increases in the effectiveness of university adult education?

In the following, we will focus on the first question discussion the degree of the cooperation of university with external stakeholders in adult education.

The projects adopted a Multiple-Case Study research strategy with embedded units of analysis (Yin, 2014), which compared different tertiary level work-based or work-related programmes for adult learners (>25) both within and across a cluster of EU Member States (CZ, DE, ES, FL, UK) and Turkey. Theoretically, LETAE has three components: an individual focus on personal development, perceptions and behaviour; an organisational focus on processes, structures, functions and collaborations; and a social element in relation to issues of inclusion, transitions and outcomes. Each partner selected three case studies.

The project is specifically concerned with the relevance of university provision and its impact on adult learners in the labour market and its influence on their work performance. For this reason, examples of business-university cooperation in the field of initial education programmes, in which the majority of participants enter direct from compulsory education, were excluded. This included for example programmes like Nursing and Teaching, Medicine and Dentistry where it could well be argued that these also offer what might be seen as workbased and work-related learning (Ramage, 2014). Whilst this is undoubtedly true, the focus here is on broader conceptions of work-based and related learning and as noted at the level of collaboration and partnership between external stakeholders and institutions of higher education in the provision of WBL programmes.

In the following section, we explore contextual information putting emphasis on the six countries under scrutiny in LETAE. In the third section, we provide a short analysis of the 
respective national landscapes of university adult education using two dimensions: a) the degree of institutional diversity of higher education and b) the identified focus of university adult education. We focus on two aspects of the EU lifelong learning strategy: a) opening the higher education for non-traditional learners (permeability) and b) the constant updating of knowledge, skills and competences of the working population (continuous training). This allows us to identify the United Kingdom and Spain as two countries, with very different university adult education strategies. While in the UK-higher education system, the strategic focus lies on permeability, the Spanish system focuses its attention on continuous training mainly in the form of post-graduate programmes. In the fourth section, we then present the cases studied in both countries in the course of the LETAE project to analyse the relevance of the university-enterprise cooperation for both strategies. We will especially discuss the issue of work-oriented learning. In the final section, we will present a general conclusion.

\section{National context data}

Having outlined a number of theoretical and policy debates at the national and EU levels it is instructive to note how and in what ways the socio-economic structural changes noted above and the policy proscriptions implemented in order to try and respond and address the social impact of the changes have manifested themselves in each of the LETAE member states. In order to provide some context within which to situate the case studies, it is instructive to have a brief look at some comparative data related to education, training and employment. In addition, we also provide details on education expenditure as a percentage of GDP and also in relation to student tuition charges and support. To allow comparison we adopt the ISCED 2011 classification (UNESCO, 2011) unless specified.

It is suggested that one measure of national interest in relation to post-compulsory education is the support provided in relation to not only the share of GDP it allocates to compulsory and post-compulsory education; but also how students finance their tuition and subsistence. Education at a Glance (OECD, 2014) provides details on the percentage of GDP (Gross Domestic Product) each of the partner countries spends on tertiary and non-tertiary education. 


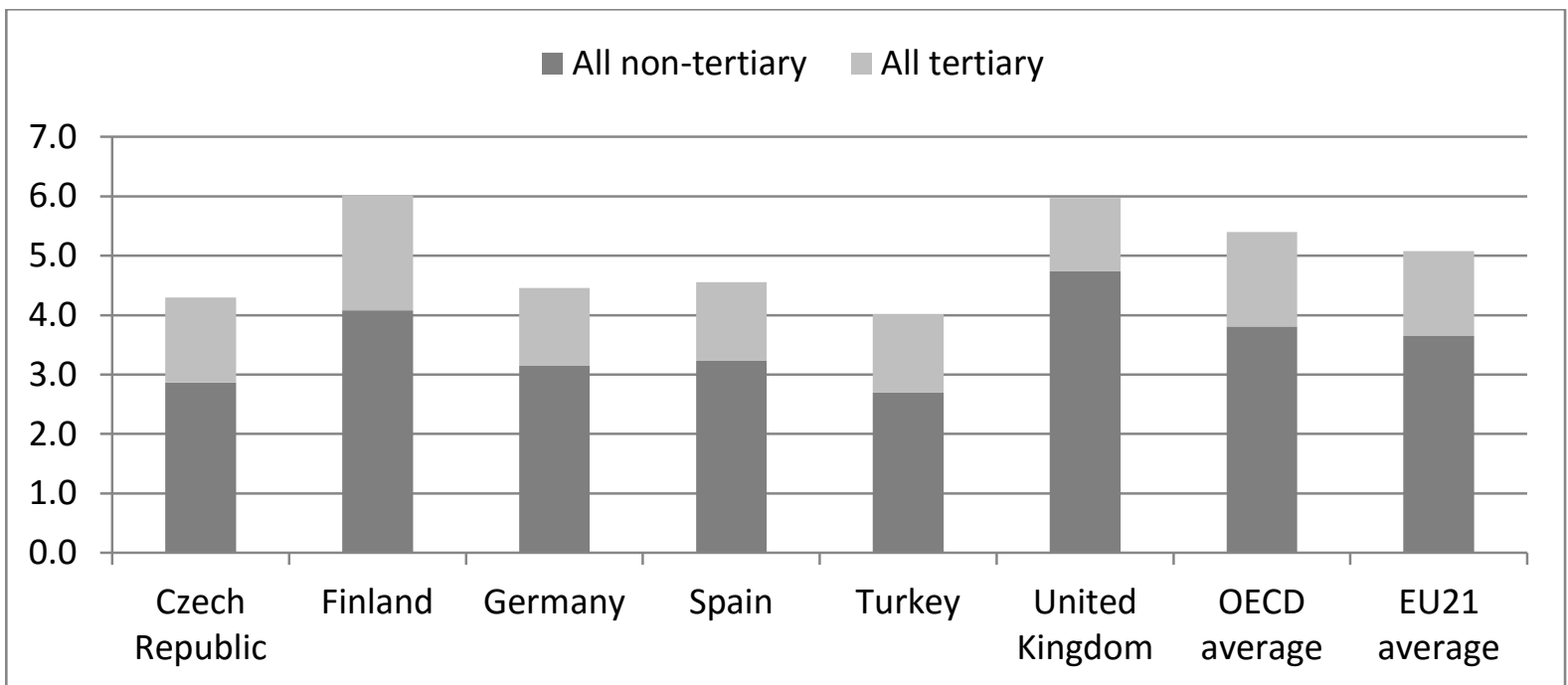

Figure 1: Expenditure on educational institutions as a percentage of GDP, by level of education -2011. Source: adapted from OECD, 2014: Table B2.1, p230

Overall, on both tertiary and non-tertiary, only the UK and Finland spend a greater percentage of GDP in comparison with not only the other partner countries; but also than the OECD and EU21 averages (Figure 1). However, it is suggested that the effects of increased marketization of tertiary education in the UK can also be seen; in that it not only spends less than project partners but also less than the OECD and EU 21 averages on tertiary level education. The four other partner countries devote a similar level of resource to both tertiary and non-tertiary education although the levels of spending on non-tertiary are lower than EU and OECD averages.

Table 1: Fees and financial support for higher education

\begin{tabular}{|c|l|l|}
\hline & \multicolumn{1}{|c|}{ Fees } & \multicolumn{1}{|c|}{ Support } \\
\hline CZ & $\begin{array}{l}\text { Minimal administration charge and no fees; } \\
\text { international students pay no fees unless in } \\
\text { foreign language instruction }\end{array}$ & $\begin{array}{l}\text { Some support dependent upon need, } \\
\text { excellence, location - family allowances and } \\
\text { tax benefits for parents }\end{array}$ \\
\hline DE & $\begin{array}{l}\text { Small administrative charge but no fees - no } \\
\text { fees EU, outside EU and EAA members }\end{array}$ & $\begin{array}{l}\text { General public and merit based grants plus } \\
\text { loans (age limited <30) - family allowances } \\
\text { and tax relief }\end{array}$ \\
\hline ES & $\begin{array}{l}\text { Multiple fees systems based on ECTS; } \\
\text { exemptions by need; individual } \\
\text { responsibility (15-25\% of fees) - non EU } \\
\text { higher fees }\end{array}$ & $\begin{array}{l}\text { Tuition fee waiver plus national grant - no } \\
\text { tax benefits or family allowances }\end{array}$ \\
\hline FI & No fees & Study grant and housing supplement - \\
\hline
\end{tabular}




\begin{tabular}{|c|c|c|}
\hline & & $\begin{array}{l}\text { income dependent }- \text { study loans available }- \\
\text { no tax benefits or family allowances }\end{array}$ \\
\hline HU & $\begin{array}{l}\text { State funding dependent upon performance } \\
(57 \%) \text { others pay fees (max } € 5,500)- \\
\text { international pay same as non-state funded }\end{array}$ & $\begin{array}{l}\text { Needs based grants }- \text { merit based for state } \\
\text { funded; and state subsidised loans - no tax } \\
\text { benefits or allowances }\end{array}$ \\
\hline IT & $\begin{array}{l}\text { Fees differentiated by need, area of study } \\
\text { and pt/ft. ( } € 1300 \text { average }) \text { - international pay } \\
\text { same rates }\end{array}$ & $\begin{array}{l}\text { Public grants for needs and for merit - } \\
\text { varied by circumstances }- \text { tax benefits for } \\
\text { parents; no loans or allowances }\end{array}$ \\
\hline NL & $\begin{array}{l}\text { All students pay fees }(€ 1900) \text { - outside EEA } \\
\text { institutional decision but higher }\end{array}$ & $\begin{array}{l}\text { Age limited }(<30) \text { general grants }- \text { some } \\
\text { loans after graduation }- \text { no tax benefits or } \\
\text { allowances }\end{array}$ \\
\hline TK & $\begin{array}{l}\text { Public universities differential fees morning } \\
\text { or evening; not for profit fee discounts } \\
\text { available; } 1^{\text {st }} \text { and } 2^{\text {nd }} \text { Cycle differential }\end{array}$ & $\begin{array}{l}\text { Various forms of grants in form of } \\
\text { scholarships and learning credits; loans - no } \\
\text { tax benefits or allowances }\end{array}$ \\
\hline \multirow[t]{2}{*}{ UK } & $\begin{array}{l}\text { England: expensive tuition fees (max } \\
€ 11,000 \text { p.a.) repayable as income } \\
\text { contingent for home and EU students; } \\
\text { international fees not regulated }\end{array}$ & $\begin{array}{l}\text { Low income grants now abolished - loans } \\
\text { repayable as with fees - no tax benefits or } \\
\text { allowances }\end{array}$ \\
\hline & $\begin{array}{l}\text { Scotland: no tuition fees for home and EU - } \\
\text { but fees payable by Rest of UK students; } \\
\text { International fees unregulated }\end{array}$ & $\begin{array}{l}\text { Grants for low income and loans - income } \\
\text { contingent repayable - no tax benefits or } \\
\text { allowances }\end{array}$ \\
\hline
\end{tabular}

Source: adapted from Eurydice 2014

There is greater disparity when the costs of higher education are compared across the partner countries. Table 1 is adapted from National Student Fees and Support Systems (Eurydice, 2014) and provides a very brief overview of the most salient elements of the costs of higher education and how and in what ways this is supported by the state or increasingly the contribution that is expected from the individual students either upfront or in the form of income contingent repayable loans. Two things are apparent from the table, illustrated by the two extremes responses to student funding; England in the UK represents the highest fees, and it is argued the most commodified HE system in Europe, while with no fees at all at undergraduate level Finland perhaps represents best the notion of HE as a truly public good.

We now turn to look at the distribution of qualifications across the population of the LETAE partners and the EU28 and provide data for pre- and post-crisis. Table 2 provides details of those aged 25-64 by education measured by ISCED 2011 for both 2007 and 2014 and by gender.

Overall, a comparison of the data from 2007 (prior to the economic crisis) and 2014 identifies some general trends: 
a) A reduction in the rate of people with low levels of educational attainment, although the magnitude is relatively small suggesting much has to be done if skill levels suggested in Europe 2020 and related predictions are to be reached. Of particular interest, the country with the lowest levels of ISCED 0-2 for both males and females is the Czech Republic where the proportion is 12 times lower for males than in Turkey in 2014 and about 8 times lower for females. Given that the data covers 25-64 year olds it suggests a relatively high level of general education in the population.

b) In relation to mid-level attainment; the Czech Republic again is distinct in terms of the share of the population for those with ISCED 3-4; a slightly similar picture emerges in Germany although not to the same extreme. While it could be argued that this reflects the strong vocational sector in Germany, in the Czech Republic as we shall see many senior jobs are held by those with only mid-level qualifications representing perhaps the different trajectories of the labour market in the two countries.

c) There has been an increase in all economies presented in the rate of people with high education attainment and the most advanced economy (as measured by the proportion with high level qualifications) would appear to be Finland. It could also be argued that it represents rather the 'public good' nature of free higher education. This is particularly noticeable in relation to the proportion of females with high level qualifications in the Finnish population.

d) Finally, only Spain could be said to exhibit an 'hour glass' economy in terms of the relative share of qualifications in the employed population.

Table 2: Population share (\%) by level of education (ISCED, 2011) and gender (age 25-64): 2007 and 2014

\begin{tabular}{|c|ccc|c|c|c|c|c|c|c|c|c|c|}
\hline & \multicolumn{5}{|c|}{2007} & \multicolumn{5}{c|}{2014} \\
\hline & \multicolumn{3}{|c|}{ Male } & \multicolumn{3}{c|}{ Female } & \multicolumn{3}{c|}{ Male } & \multicolumn{3}{c|}{ Female } \\
\hline & $0-2$ & $3-4$ & $5-8$ & $0-2$ & $3-4$ & $5-8$ & $0-2$ & $3-4$ & $5-8$ & $0-2$ & $3-4$ & $5-8$ \\
\hline EU28 & 27.8 & 49.0 & 23.2 & 30.8 & 45.5 & 23.8 & 23.7 & 48.4 & 27.9 & 24.3 & 45.0 & 30.7 \\
CZ & 6.1 & $\underline{79.0}$ & 14.8 & 12.8 & $\underline{74.6}$ & 12.6 & 4.8 & $\underline{74.5}$ & 20.7 & 8.8 & $\underline{68.8}$ & 22.4
\end{tabular}




\begin{tabular}{|c|ccc|ccc|ccc|ccc|} 
DE & 12.6 & $\underline{59.6}$ & 27.8 & 18.6 & $\underline{60.6}$ & 20.8 & 11.3 & $\underline{58.3}$ & 30.5 & 14.9 & $\underline{61.4}$ & 23.7 \\
ES & 49.7 & 21.7 & 28.6 & 49.0 & 21.1 & 30.0 & 45.2 & 22.0 & 32.8 & 41.6 & 21.9 & 36.5 \\
FI & 21.7 & 47.2 & 31.1 & 17.3 & 41.1 & $\mathbf{4 1 . 7}$ & 16.1 & 48.7 & 35.2 & 10.8 & 40.7 & $\mathbf{4 8 . 5}$ \\
UK & 23.5 & 44.9 & 31.6 & 29.8 & 37.7 & 32.5 & 19.6 & 41.2 & $\mathbf{3 9 . 2}$ & 22.0 & 36.1 & $\mathbf{4 1 . 9}$ \\
TR & 66.9 & 20.5 & 12.6 & 79.8 & 12.4 & 7.7 & 61.3 & 21.0 & 17.8 & 73.6 & 13.6 & 12.8 \\
\hline
\end{tabular}

Source: adapted from Eurostat.

From a labour market perspective, and related to the policy prescriptions outlined above, the crucial question is, if an increasing number of people with high levels of education can be absorbed into the labour market at an adequate level (Bartlett, 2013; Flisi et al., 2014; ILO, 2014). One way to examine this is to look at the level of educational attainment at different levels of the labour market using the International Standard Classification of Occupation (ISCO). While it might be expected for some people with low levels of education to obtain high level jobs, through performance, progression or innate talent; it is suggested that it is more problematic if large numbers of those with high level qualifications are employed in low level occupations resulting in underemployment, over qualification, or; what is termed a 'mismatch' between qualifications and employment.

An analysis was undertaken on ISCED (ISCED, 2011) occupational classification levels mapped onto ISCO (ISCO-08) labour market categories for adults employed in ISCO 1-9 for males and females aged 25-64 in the partner countries and the EU28 averages for 2007 and 2014.

In relation to positive mismatch, males in Turkey with low levels of education $(14.5 \%)$ are around twice as likely as the EU28 (6.1\%) to have achieved high level occupations (ISCO Levels 1-3); with the Czech Republic having considerably higher proportions of those with ISCED Levels 3-4 having high level jobs in 2007. By 2014 however, this mismatch had been reduced and there had been a rise for all partner countries for those with high educational attainment (ISCED 5-8). One possible interpretation is that in tightening labour markets educational qualification becomes a more important sorting device; while, conversely the reduction in those with low attainment reaching higher level jobs may be a sign of reduced social mobility. 
In relation to negative mismatch: for males in 2007, the UK exhibited levels of apparent underutilisation (8.5\%) far higher than other LETAE partners and also the EU28 average (4.5) for those with high-level qualifications in ISCO level 8-9 and while that reduced by 2014, the UK still had more than twice the proportion of those with high levels of attainment (ISCED5-8) in lower level occupations. Interestingly, Spain, specifically in Clerical and Sales occupations (ISCO 4-5) for both males and females, levels of education appear to make little difference to labour market position.

If we look at matching between education and occupation for females a similar picture emerges although the scale of underutilisation is more diverse and this may be related to gender inequality in access to the labour market, structural differences and cultural gender roles. It is suggested that Spain, Turkey and Finland provide the best opportunity for them to realise their potential in terms of achieving employment at a level for which they are educated with $89 \%, 84 \%$ and $87 \%$ respectively with higher levels of attainment (ISCED 5-8) in higher level occupations (ISCO 1-3); as with males in higher level occupations, matching at the top end increased by 2014. Finally, when we examine employment at the lower end of the occupational scale (ISCO8-9) we can see what might be considerable underutilisation of females with mid-level qualifications in the Czech Republic and Finland while between 1 in 8 and 1 in 10 in Finland, Spain and the UK with high levels of attainment were in elementary occupations which is around twice the EU28 average (5.8\%).

In general, it would appear that since the crisis of 2008 there is increased matching of education to employment levels at the top end of the labour market; although it would also appear that the proportion of those who could be identified as underutilised increased as a result of the recession. The analysis, although open to charges of over simplification does suggests that education is not a guarantee of high-level employment and that in the current labour market there appears to be considerable underutilisation of educational attainment across the partner countries although there is considerable variation both within and across countries and by gender. Correspondingly it also suggests that low qualifications are not an insurmountable barrier to gaining employment in high level occupations as measured by ISCO although this appears to be reducing. In general, it would also appear that the proportion of those who could be identified as underutilised increased as a result of the recession caused by the financial crisis of 2008. In addition, it seems that increasing the rate 
of people with higher education, which is an expressed objective of Europe 2020, may be accompanied by an increasing difficulty for these people to find a job, which is adequate to their education level.

\section{University - stakeholder cooperation in adult education}

Lifelong learning at higher education institutions is not the main subject of educational research, but there are several European projects working on this and related fields. In addition to the LETAE project, there have been a number of projects, which are providing insights on the national landscapes. In several works derived from these projects, the diversity and complexity of the European landscapes of lifelong learning at universities are observed (see for instance: Davies, P., 2007a and 2009; de Viron, F. \& Davies, P.; 2015 and EUA reports: Sursock, A. and Smidt, H., 2010; and Smidt, H. and Sursock, A. 2011).

Smidt and Sursock (2010: 66) concluded that in the EU, lifelong learning at universities is mainly interpreted in two ways:

- Provision of education within a lifelong perspectives including all types of learning: formal, informal and non-formal learning; and,

- Provision of discrete activities: e.g., professional upgrading, continuing education, distance education, university courses for junior, mature and senior learners, preparatory courses, and part-time education to a greater variety of learners. .

In their Trend report; Smidt and Sursock (2010: 68) suggested that professional development courses, continuing education for adults and distance learning are the main lifelong learning activities at higher education institutions.

More directly relevant to the focus of LETAE, the recent Eurydice report Adult Education and Training in Europe: Widening Access to Learning Opportunities (2015) identified a range of barriers common to those raised in debates on Work-based or -related Learning. The main constraints identified were the difficulties in combining education and training with family life and responsibilities; time issues in terms of conflicts with work schedules; a lack of prerequisite qualifications and difficulties associated with recognition of prior learning; and a range of financial issues. The report also stressed the need for outreach and guidance activities to raise awareness and provide robust information in the area of 
WBL; itself the focus of an ELGPN (European Lifelong Guidance Policy Network) Report: Work-based Learning and Lifelong Guidance Policies.

Another relevant piece of research is provided by the Work Based Learning as Integrated Curriculum (WBLIC) project (2013) funded by the Lifelong Learning Programme aimed at identifying best practice in WBL. They note that the dominant approach to WBL in Europe appears to be through work placements and reflection and that it tends to be concentrated in newer rather than traditional universities. They also note that alternative routes or permeability into higher education are rare and the UK has a significantly higher proportion (28\% compared to around $5 \%$ in other European countries) entering through nontraditional entry routes. In terms of employer engagement they report that the evidence is limited and note that WBL is seldom identified or reported as a distinct entity in strategic policy documents and when it is, the data does not allow a full understanding of its scope and the scale of future potential.

Many of the issues identified above reflect concrete conditions in a number of the LETAE case studies. So too are many of the challenges in relation to: employer engagement, assessment, funding, and costs and benefits to learners, academic institutions and external stakeholders who work in collaboration and/or partnership to deliver opportunities of work oriented adult education and universities.

\section{Case studies}

Having provided a range of comparative data on the national landscape in relation to educational attainment and outcomes we return to our case studies. While there is no space here to provide in depth details of the 18 case studies selected for the project; we do provide details of all cases on a number of criteria. However a number of points about the case should be noted.

While the project laid down a number of selection criteria for case selection, in a number of contexts it was not possible to select programmes that satisfied all criteria for all partners. This is partly explained by the different landscapes and context in operation in the selected countries, and the historical development of the vocational and academic sectors with reference to labour market structures and stratification. 
Of the 18 cases, seven were focused on managerial or professional level staff, while another six were in engineering related fields with the remainder more diverse. In terms of duration seven of the cases were six months or less and often part-time; while six were longterm and involved at least three years commitment by the learner. Eleven of the cases were focused on post-graduate learners with an existing degree with only four cases focusing on upskilling existing workers in a specific field and this is reflected in the entry requirements required. Six of the cases were based on full-time attendance and while three of the part-time cases included blended learning, only one UK-case operated on a distance model. In relation to the delivery of the programmes nine of the cases were delivered by solely by academic staff or in conjunction with practitioners and specialists in the relevant field; while in the Spanish and Turkish cases academics were selected and then retained (or not) based on programme evaluation. Finally, in terms of outcomes, the Spanish and Turkish cases offered University Certificates outside of formal recognition (Bologna) structures, while the Finish cases all offered transferable ECTS points and a Certificate. The three UK cases all led to the award of a recognised qualification at ISCED 5 or 6 . Two of the German programmes led to certificates within the Bologna Scheme (Bachelors) and the third was a programme preparing for participation in Bachelor programmes. In contrast the Czech cases, perhaps representing the lower level of adult work related learning offered certificates of completion or institutional credits.

While there is no room here to give a detailed exposition of the differences in the partner countries it is suggested that it is possible to infer some general characteristics in relation to the general orientation of university adult education in the six partner states. It is suggested that the Finnish, Spanish and Turkish universities focus on continuous training programmes. While the Turkish universities include VET centres, their programmes address a broad range of learners not only postgraduates but tend to be very short course and might be considered more as CPD. In comparison, the Finnish and Spanish universities have a specific focus on postgraduate continuous training. In the Finnish case, as noted, this is within existing and national award structures and ECTS points should be recognised across EU member states; in the Spanish cases, while two award University Masters these are not recognised at a national or international level which is linked to the specific structure of its education system, outlined in more detail below. 
In Germany and the UK/Scotland, the focus lies more on the issue of permeability and transferability that facilitates in theory at least the access of people with non-academic entry qualifications to degree level. This does not mean that universities in both countries do not offer postgraduate adult learning programmes, but the main focus of the policies lies on the integration of non-traditional learners through officially certified programmes. The cases selected in Germany are two bachelor programmes specifically designed for adult learners and one programme, which prepares adults for their participation in bachelor programmes. The three UK cases each target a specific group but all are closely linked to the learner's current employment and two of the programmes also allow professional accreditation in addition to the formal degree award.

Finally, as suggested above the Czech Republic is a specific case, as the development of adult education at universities seems to be in its initial phase and has not yet acquired a specific profile and this is perhaps a result of it specific context given the relatively high historical levels of educational attainment noted earlier.

In the following section, we will take the Spanish and the UK cases as examples of the specific orientation of university adult education programmes to analyse the configuration of the university/enterprise collaboration. It is suggested that the UK/Scotland and Spain offer quite distinct approaches (OECD, 2012) in relation to the general strategic focus of university adult education systems strategically focused on postgraduate continuous training (ES) or permeability (UK/Scotland).

\section{Some concluding remarks}

We have set out above an overview of various aspects of work-based and -related learning in higher education involving partnerships and collaboration with external stakeholders. We have positioned this study within the context of various EU and national policy documents which call for the creation of a high-skilled workforce to effectively harness the high value and high skill employment opportunities said to be required in the knowledge economy. We have noted that despite some limited successes, the scale and scope of cooperation in work based and related learning has not developed to the extent that was envisaged. Bottlenecks still exist in relation to the recognition and accreditation of prior 
learning and experience; and despite some success genuine partnerships between enterprises and or sectoral organisations appear to be thin on the ground.

We also noted some differences within and across the partner countries and how this and national policy and educational structures can hinder or enhance greater collaboration between both academic and vocational sectors but also in promoting collaborations partnerships with industry and trade unions. We can highlight some of these differences by looking at the quite different trajectories and strategies followed by the case studies in Spain and the UK/ Scotland. In Spain, partnership and engagement with industry is often seen as additional income in the form of continuous training, generally to those with existing qualifications, while in the UK it is as in the cases selected may also form part of the institutional prospectus for Bachelors level study in addition to post-graduate offerings. However, the relative dearth of robust data on the true scale and scope of work based learning provision in higher education delivered in partnership or collaboration means that progress is hard to track. It is also complicated by the continued lack of any real progress in systems of accreditation of prior learning and experience despite policy commitments and rhetoric over many years.

The programmes selected in Spain and the UK do not pretend to be representative of the national panorama, but are good examples of the cooperation between universities and stakeholders. They also showed differences between both countries. In Spain, postgraduate programmes that are not integrated in the Bologna scheme were selected. We are talking about programmes, whose design and implementation was leaded by enterprises. On the contrary, the cases from the UK are all programmes included in the Bologna schema addressing non-traditional learners. It seems worth noting that in five of the six programmes analysed in both countries, stakeholders (enterprises or trade unions) are leading the cooperation. The universities fulfilled more a role of a training provider and they guarantee the academic quality of the programmes. We also highlight that five of the six programmes (three in the UK and two in Spain) have a long duration in time as well as in credits. Moreover, in all of these cases, a considerable part of the programme are developed at the work place. That means the staff of the enterprises, which are actively participating in teaching process and selected by the enterprises, have a considerable responsibility for the learning process. 
All cases confirmed the relevance to link learning to the work processes. This seems quite normal for tailor-made programmes, but results of a previous project (Krüger, 2014) about University adult education (especially the Spanish cases) indicate the relevance to link learning to work also for open programmes. But the cases of open programmes call also the attention to the difficulties to establish a coherent linkage and to assure the learning quality of the internships and stages.

In spite of us having injected some caution to our analysis, we have observed that the sub-utilization of highly-educated work forces has been recurrent in the last decade in spite of its variation from country to country. Especially in the two aforementioned countries - UK and Spain - this is a highly relevant question as the mismatch is at a high level. And recent analysis of the labour market has suggested that since the crisis many of the new jobs which have been created have been in the low-skill and low paid sector. According to the European Commission (EC 2012: 31): "Fluctuations in EU job numbers since the crisis began have been driven mainly by part-time work and temporary contracts."

This is given some credence by the findings of European Jobs Monitor 2015 (Eurofound, 2015:1) which notes that recent trends indicate a downward skew in employment distribution with more growth in lower-paid employment and comment that this "raises the spectre of growing low-productivity employment, where output and, ultimately, living standards fail to rise despite an increase in job opportunities.."

This indicates that equating higher education as access to good jobs - also considering the trend towards generalisation of higher education promoted by the actual EU strategy Europe 2020 - is not valid any more in many EU-countries. This suggests that, in the future major social investments in continuous training and governments must provide an adequate offer of tertiary adult education oriented to the labour market to support people in critical periods of labour market transitions. And that this requires a greater degree of cooperation between higher education institutions including universities; and stakeholders to provide adequate training and education provisions. 


\section{Acknowledgements}

This publication is based on the results of the project LETAE "Labour Efficiency of Tertiary Adult Education". It is co-funded with support from the European Commission (539382LLP- 1-2013-1-ES-ERASMUS-EQR).

\section{References}

Bartlett, W. (2013) Skill Mismatch, Education Systems, and Labour Markets in EU Neighbourhood Policy Countries, WP5/20 Search working paper, http://goo.gl/1ZjnTd (accessed: November 2016).

Bell, D.N.F. and Blanchflower, D.G. (2013) Underemployment in the UK Revisited, National Institute Economic Review 224: F8-F22.

Buhr, R., Freitag, W., Hartmann, E. A., Loroff, C., Minks, K.-H. \& Stamm-Riemer, I. (Eds.) (2008) Durchlässigkeit gestalten! Wege zwischen beruflicher und hochschulischer Bildung.

CEDEFOP (2012) Permeable education and training systems: reducing barriers and increasing opportunity, Briefing Note November 2012. http://goo.gl/wlzQGh (accessed: November 2016).

Department for Innovation, Universities and Skills (DIUS) (2008) Higher Education at WorkHigh Skills: High Value. Sheffield: DIUS.

Flisi, S., Goglio, V., Meroni, E, Rodrigues, M., Vera-Toscano, E. (2014) Occupational mismatch in Europe: Understanding overeducation and overskilling for policy making. European Commission, Joint Research Centre, Institute for the Protection and Security of the Citizen. https://goo.gl/Ok7OVn (accessed: November 2016).

Harwood, J. (2010) Understanding Academic Drift: On the Institutional Dynamics of Higher Technical and Professional Education, Minerva, 48, pp.413-427.

Hippach-Schneider, U. (2014) Academisation or vocational drift: International developments in the tertiary sector of education. Bonn: BIBB. http://goo.gl/ujrJ2D (accessed: November 2016). 
ILO (2014) Skills Mismatch in Europe, ILO Dept. of Statistics, http://goo.gl/EEG5P5 (accessed: November 2016).

Jung, D. B. (2015) Effectiveness of higher education to labor productivity. PEOPLE: International Journal of Social Sciences Vol. 1, No.1, pp. 11-22, July 2015.

Kitching, C. (2015) Effective Teaching for New tertiar6y Students. PEOPLE: International Journal of Social Sciences. Special Issue, Volume 1; Issue:1, 2015, pp. 1-10

Krüger, K. (2014) Social Effectiveness of Tertiary Education for Adults in Mid-life. Barcelona/Oldenburg. 2014.

Krüger, K. \& Jiménez, L. (2008) The social function of higher education in the social models of the European knowledge society. Barcelona, Budapest, Lódz, Modena, Nijmegen, Wien. 2008.

Kuhn, H.-J., Baethge, M., Hinz, P., Löhrmann, S., Poltermann, A., Stern, C., Tenorth, H.-E. \& Volkholz, S. (2009) Bildungsgerechtigkeit im Lebenslauf - Damit Bildungsarmut nicht weiter vererbt wird. Berlin, Heinrich Böll Stiftung.

Kyvik, S. (2004). Structural changes in higher education systems in Western Europe. Higher Education in Europe, 29(3), 393-409.

Kyvik, S. (2009) The Dynamics of Change in Higher Education Expansion and Contraction in an Organisational Field, Higher Education Dynamics Series, Volume 27, Springer.

Lafont, P. and Pariat, M (2012) Review of the recognition of prior learning in member states in Europe. University Recognition of Prior Learning Centers. http://goo.gl/La2mqY (accessed: November 2016).

Mayer, K. U. and Solga, H. (Eds.) (2008) Skill Formation: Interdisciplinary and CrossNational Perspectives. Cambridge: Cambridge University Press.

Ramage, C. (2014), Learning to learn through university accredited work-based learning: a threshold conception, Journal of Workplace Learning, Vol. 26 (8) pp. 488 - 510.

Skorstad, E. J. and Ramsdal, H. (Eds.) (2009) Flexible Organizations and the New Working Life - A European Perspective, Surrey: Ashgate.

Smeby, J-C. (2015) Academic drift in vocational qualifications, in From Vocational to Professional Education: Educating for Social Welfare in (eds) Jens-Christian Smeby and Molly Sutphen, ch2 London: Routledge. 
Standing, G. (2011) The Precariat: the New Dangerous Class, London: Bloomsbury Academic.

Streeck, W. (2011) Skills and Politics: General and Specific, Ch7 in The Political Economy of Collective Skill Formation, edited by Marius R. Busemeyer and Christine Trampusch . New York: Oxford University Press.

Trow, M. (1974) Problems in the Transition from Elite to Mass Higher Education. Berkeley: Carnegie Commission on Higher Education.

UNESCO (2011) International Standard Classification of education. UNESCO Institute for Statistics. http://goo.gl/DXSRzt (accessed: November 2016).

UnionLearn (2013) Building trade union support for workplace learning throughout Europe. London: TUC. https://goo.gl/qjt5K7 (accessed: November 2016).

UVAC (2005) Integrating Work-based Learning into Higher Education A report by the University Vocational Awards Council, http://goo.gl/542hD9 (accessed: November 2016).

UVAC (2009) Funding Higher-Level Work-based Learning; A paper prepared for HE@Work by the University Vocational Awards Council June 2009. UVAC. http://goo.g1/Qp3Va5 (accessed: November 2016).

Yin, R.K. (2014) Case Study Research: Designs and Methods, (5 ${ }^{\text {th }}$ Edition) London: Sage.

Yorke, M. and Knight, P. (2006) Embedding employability into the curriculum, York: HEA. https://goo.gl/LUJ14S (accessed: November 2016). 